\title{
Hallux Sesamoiditis - Radiological Diagnostics and Conservative Management
}

\author{
Igor Borić ${ }^{1}$, Marko Pećina ${ }^{2}$, Maja Mirković3 ${ }^{3}$ Tatjana Cicvara Pećina ${ }^{4}$, Damir \\ Matoković ${ }^{5}$, Mihovil Plečko ${ }^{6}$, Ivo Dumić-Čule ${ }^{4}$ \\ ${ }^{1}$ St. Catherine Specialty Hospital, Zabok \\ ${ }^{2}$ Department for Orthopedics, School of Medicine, University of Zagreb, Zagreb \\ Polyclinic for orthopedics, physical medicine and rehabilitation "Kinematika", Zagreb \\ ${ }^{4}$ Department of diagnostic and interventional radiology, University Hospital "Dubrava”, Zagreb \\ County General Hospital Požega, Požega \\ ${ }^{6}$ Department for Orthopedics, University Hospital Center Zagreb, Zagreb
}

ABSTRACT:

Sesamoid bones play an essential role in first metatarsophalangeal (MTP) joint biomechanics, together with other articular surfaces, joint capsule, plantar fascia, ligaments and tendons. They are prone to different acute and chronic injuries, such as acute fracture, stress fractures, chondromalacia, avascular necrosis, bursitis degenerative changes, inflammation etc., all of which clinically manifest as a painful condition and are often diagnosed under a broad term called sesamoiditis. The mechanism of injury is most commonly associated with overuse of the anterior part of the sole of the foot accompanied by excessive dorsiflexion of the great toe. Sesamoiditis presents with pain and localized swelling in the projection of the tibial sesamoid bone, which is affected more frequently than the fibular one. Diagnostic radiology plays a key role in determination of etiology of the disease, as well as in planning of it's treatment. Typical radiological examination includes weight-bearing dorsoplantar, lateral, oblique medial and oblique lateral radiographs of the foot, together with a direct axial radiograph of sesamoid bones. Computerized tomography is used for distinction of acute fractures and early stage of stress fractures from other pathological conditions. Magnetic resonance imaging allows differentiation between bony pathology and soft tissue conditions. Sesamoiditis management is primarily conservative and it depends on duration and severity

OPEN ACCESS

Correspondence:

Mihovil Plečko MD mplecko@kbc-zagreb.hr orcid.org/0000-0001-6569-9287

This article was submitted to RAD CASA - Medical Sciences as the review article

Conflict of Interest Statement: The authors declare that the research was conducted in the absence of any commercial or financial relationships that could be construed as a potential conflict of interest.

Received: 13 October 2019 Accepted: 28 November 2019 Published: 10 December 2019

Citation:

Borić I, Pećina M, Mirković M et al. Hallux Sesamoiditis- Radiological Diagnostics and Conservative Management. RAD CASA - Medica Sciences. $540=48-49$ (2019): 27 32. https://dx doi.org/10.21857/ m8vqrtzxg9

Copyright (C) 2019 Borić, Pećina, Mirković et al. This is an open-ac cess article distributed under the terms of the Creative Commons Attribution License (CC BY). The use, distribution or reproduction in other forums is permitted, provided

the original author(s) and the

copyright owners(s) are credited and that the original publication and that the original publication in this journal is cited, in accordance whit accepted adacemic practice. is permitted which does not comply with these terms. of the condition. Orthotic insoles customized according to pedobarographic findings may be useful for solving biomechanical deformities that could have led to development of sesamoiditis. Specific pads placed under the first MTP joint in order to prevent the great toe from dorsiflexion proved to be a very effective conservative treatment option. Surgical treatment is considered if conservative methods fail to provide sufficient management of the condition.

KEYWORDS: sesamoid bones; hallux; sesamoiditis; diagnostic radiology; sesamoiditis treatment;

\section{SAŽETAK:}

SEZAMOIDITIS - RADIOLOŠKA DIJAGNOSTIKA I KONZERVATIVNO LIJEČENJE

Sezamske kosti u području metatarzofalangealnog zgloba nožnog palca (hallux) dio su anatomsko-biomehaničkog kompleksa kojeg čine zglobna tijela, čahura, plantarna fascija, sveze i tetive mišića. U sklopu navedenog kompleksa sezamske kosti podložne su raznim akutnim i kroničnim oštećenjima u smislu prijeloma, stres prijeloma, hondromalacije, avaskularne nekroze, burzitisa, degenerativnih promjena, upala itd., a što se sve klinički očituje kao bolno stanje i sve se podvodi pod široki pojam sesamoiditisa. Mehanizam koji dovodi do sesamoiditisa najčešće je vezan uz prenaprezanje prednjeg dijela stopala praćenog ekscesivnom dorzifleksijom nožnog palca. U kliničkoj slici sesamoiditisa najčešći simptom je bol i lokalizirana oteklina i to u području tibijalne sezamske kosti koja je daleko češće zahvaćena u odnosu na fibularnu sezamsku kost. Radiološka dijagnostika je značajna kako u otkrivanju etiologije tako i u planiranju liječenja sesamoiditisa. Standardna radiološka pretraga obuhvaća antero-posteriornu snimku pod opterećenjem stopala, lateralnu snimku, kose snimke te aksijalnu snimku sezamskih kostiju. Kompjuterizirana tomografija pokazala se korisnom za razlikovanje akutnog prijeloma i ranog stadija stres prijeloma sezamske kosti od drugih patologija koje mogu zahvatiti sezamske kosti. MRI omogućuje diferencijaciju između koštanih promjena i promjena na mekom tkivu. Liječenje sezamoiditisa je prvenstveno konzervativno i uvelike ovisno o uznapredovalosti promjena u području cijelog metatarzofalangealnog kompleksa. Ortopedski ulošci nakon pedobarografske analize opterećenja stopala mogu otkloniti biomehaničke deformacije koje su potencijalno pridonijele razvoju sesamoiditisa. Posebni podlošci ispod metatarzofalangealnog zgloba palca u smislu sprečavanja dorzifleksije palca su vrlo korisni i efikasni u konzervativnom liječenju sesamoiditisa. Kirurško liječenje može biti preporučeno nakon neuspjelog konzervativnog liječenja.

KLJUČNE RIJEČI: sezamske kosti; nožni palac; sesamoiditis; radiološka dijagnostika; liječenje sesamoiditisa; 


\section{INTRODUCTION}

Sesamoid bones (ossa sesamoidea) were first described by Galen in the second century, who compared them with sesame seeds. Sesamoid bones are inserted into tendons of certain muscles, usually where the tendon is passing over a joint, such as in first metacarpophalangeal and first metatarsophalangeal (MTP) joints. They can less often be found in areas of interphalangeal joints both in the foot and in the hand. Also, this type of bones can be found in the lower extremity, located in tendons of triceps surae muscle, tibialis posterior muscle and peroneus longus muscle. The largest sesamoid bone is the patella, inserted into the tendon of the quadriceps muscle. Sesamoid bones can also be embedded into joint capsules or be divided by a synovial bursa from the underlying bone, wherein both cases the articular surface of the sesamoid bone is covered by hyaline cartilage. They play an essential part in first MTP joint biomechanics, together with other articular surfaces, joint capsule, plantar fascia, ligaments and tendon ${ }^{1-6}$ In this complex we find two sesamoid bones, tibial (medial) sesamoid bone embedded into the medial head of the flexor hallucis brevis muscle (FHB) and fibular (lateral) sesamoid bone embedded into the lateral head of FHB. Both of these bones are located under the head of the first metatarsal bone, with the tibial sesamoid being placed distally in comparison to the fibular sesamoid. A crest is located on the plantar surface of the first metatarsal bone, dividing two sesamoid bones and forming two joints: medial and lateral metatarsosesamoid joints. Their function is to distribute and ease the pressure produced during gait that affects the head of the first metatarsal bone, to lower the friction on the flexor hallucis longus muscle which passes between these two bones, as well as to act as a fulcrum for FHB. Sesamoid bones of the great toe ossify at age of 8-9 in girls and at age of 11-13 in boys. During the ossification process the tibial sesamoid bone can be divided into two or more parts, thus forming a bipartite or multipartite bone. Studies show that a bipartite tibial sesamoid bone has an incidence of $10 \%-30 \%$, where in fibular sesamoid bone partition rarely occurs. In $25 \%$ of the cases bipartite tibial sesamoid bone is present bilaterally.

\section{ETIOLOgY}

As a part of the first MTP joint complex, sesamoid bones are prone to different acute and chronic injuries, such as acute fracture caused by trauma ${ }^{7}$, stress fractures ${ }^{8,9,10}$, chondromalacia, osteocartilaginous injury ${ }^{11}$, avascular necrosis ${ }^{12}$, osteochondritis ${ }^{13}$, bursitis, degenerative changes, inflammation, developmental anomalies14-18, all of which is clinically diagnosed under a broad term called sesamoiditis. The mechanism of injury is most commonly associated with overuse of the anterior part of the sole of the foot accompanied by excessive dorsiflexion of the great toe ${ }^{19}$. This usually occurs in sports that involve running and jumping, especially in the initial phase of running and during sprinting. Moreover, ballet dancers often use "relevé" position of the sole of the foot, thus putting a great amount of load on the head of the first metatarsal bone ${ }^{20}$. Furthermore, deformities such as pes cavus, conditions like a rigid sole of the foot and hard surfaces where different sports are played can facilitate development of sesamoiditis, often colloquially called turf toe in such cases ${ }^{21-27}$. Injury of plantar structures of the first MTP joint in American football players were first described by Bowers and Martin in 1976. and Rodeo et al. reported that $45 \%$ of American football players have suffered from turf toe during their sports career ${ }^{18}$.

\section{Clinical pRESENTATION}

Sesamoiditis presents with pain and localized swelling in the projection of the tibial sesamoid bone, which is affected more frequently than the fibular one. Pain can occur acutely after trauma, or it can develop chronically, in a subtler way, which happens in most cases. Putting static load on the first MTP joint area and wearing certain rigid types of footwear intensifies the pain, while running could be impeded. In the later phase of the disease, pain can occur on the lateral part of the foot, as patient inverts his foot while walking to avoid putting pressure to the great toe. During dorsiflexion of the great toe sesamoid bones move distally, as well as the area painful to palpation on the affected great toe (Figure 1). Swelling is often overlooked, due to the presence of adipose tissue in this area. Passive movements in the first MTP joint can be painless. On the other hand, projection of the sesamoid bones is painful to palpation, as well as plantar flexion against resistance in the first MTP joint, thus being classical symptoms of sesamoiditis ${ }^{28}$.

\section{Diagnostics}

Diagnostic radiology plays a key role in determination of etiology of the disease, as well as in planning of it's treatment ${ }^{15,29,30,31}$. Typical radiological examination of sesamoid bones include weight-bearing
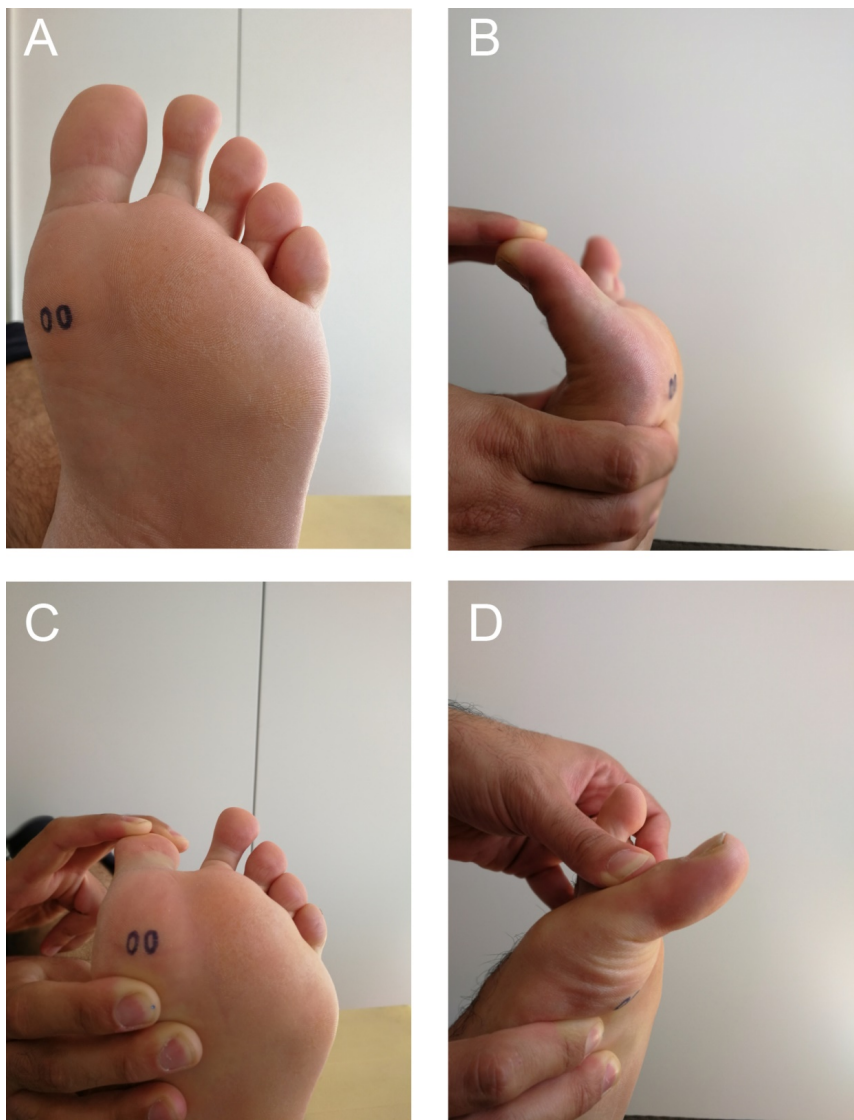

Figure1. The passive axial compression test (PACT). A) The sesamoid bones are under the first metatarsal head. B) Maximal dorsal flexion of the hallux produces distal migration of the sesamoids. C) Applying compression proximal to the sesamoids stabilizes them in their most distal position. D) Test is positive if passive plantar flexion in the metatarsophalangeal joint produces pain. 


\section{Review ArTiCle}
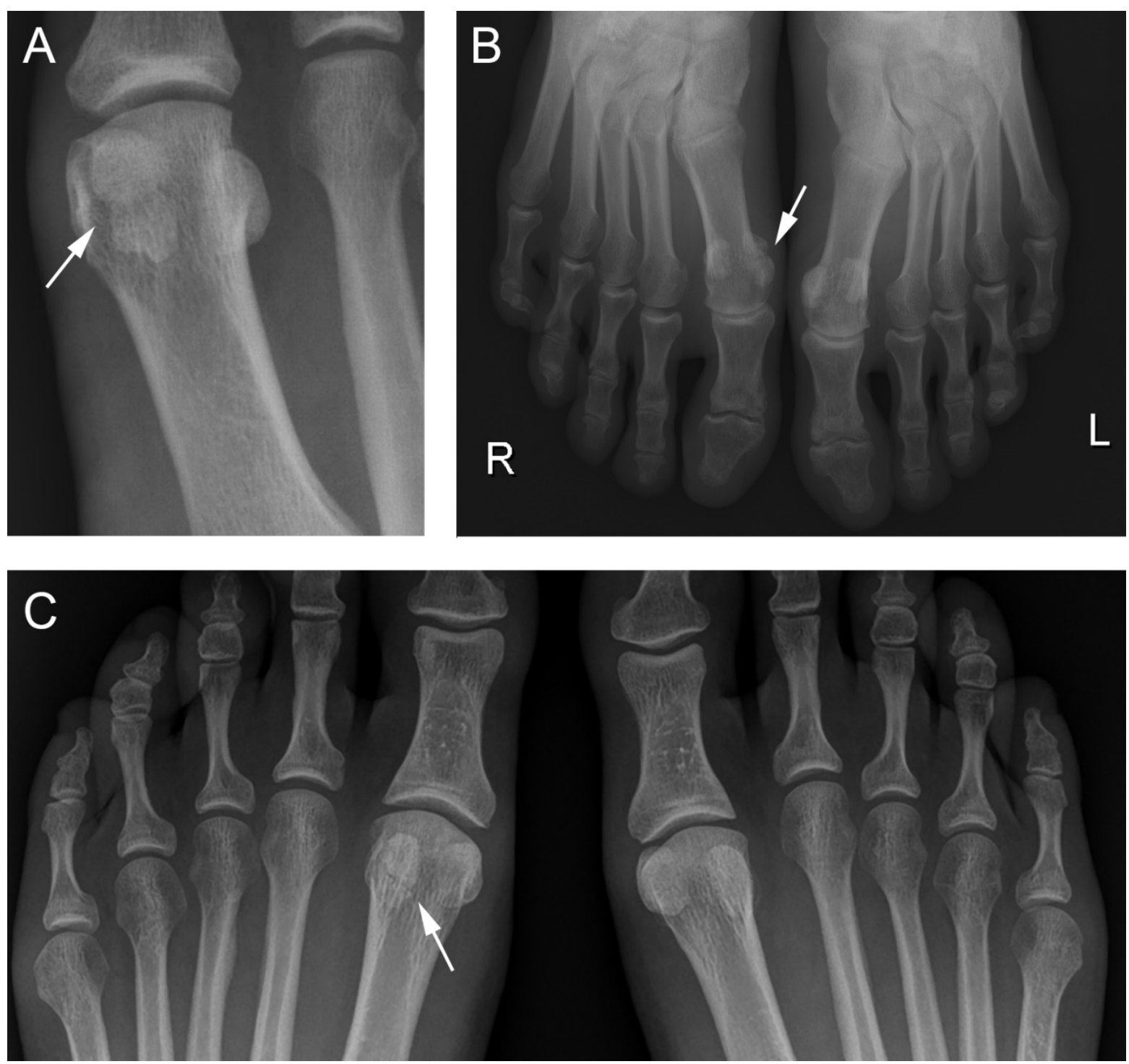

Figure2. Weight-bearing dorsoplantar radiographs of the foot shows: A) and B) bipartite tibial sesamoid bone in two different patients (arrow): bipartite bones are bigger than the undivided bone, divided fragments have smooth, round and sclerotic edges; C) fracture of the fibular sesamoid (arrow): sharp oblique fracture line.

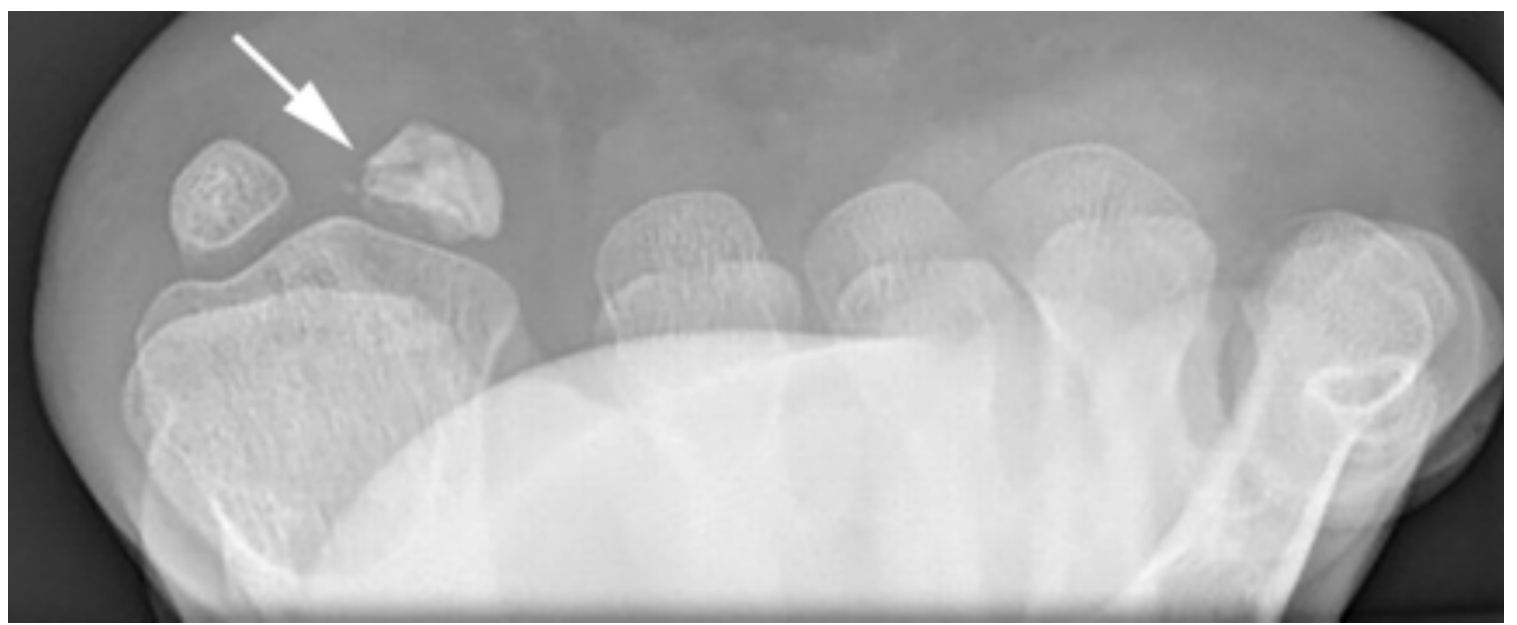

Figure3. Direct axial radiograph of sesamoid bones shows sclerotic and fragmented fibular sesamoid bone as a sign of osteonecrosis (arrow).

dorsoplantar, lateral, oblique medial and oblique lateral radiographs (dorsoplantar radiograph with the foot angled 40 degrees medially/ laterally) of the foot, together with a direct axial radiograph of sesamoid bones. For the axial sesamoid projection patient's foot is in maximal dorsiflexion with toes pulled back towards the patient, with the tangential X-ray being directed from the anterior part of the foot towards the posterior part, providing a profile image of sesamoid bones at the first MTP joint. Radiographs may show malposition, bi-/multi-partition of sesamoid bones, hallmarks of osteoarthritis of the first MTP joint, fractures, osteonecrosis, stress fractures, translation and proximal retraction of sesamoid bones, infection etc. Distinction of fracture from bipartite sesamoid bones could be done by taking radiographs of both foot, as the bipartite sesamoid bones often present bilaterally. Fractures of sesamoids typically present on radiographs as communitive puzzle-like fragments, with displacement and sharp, irregular edges. Formation of callus in follow-up radiographs may confirm fracture diagnosis. Bipartite sesamoid bone is usually bigger than the undivided bone with smooth 


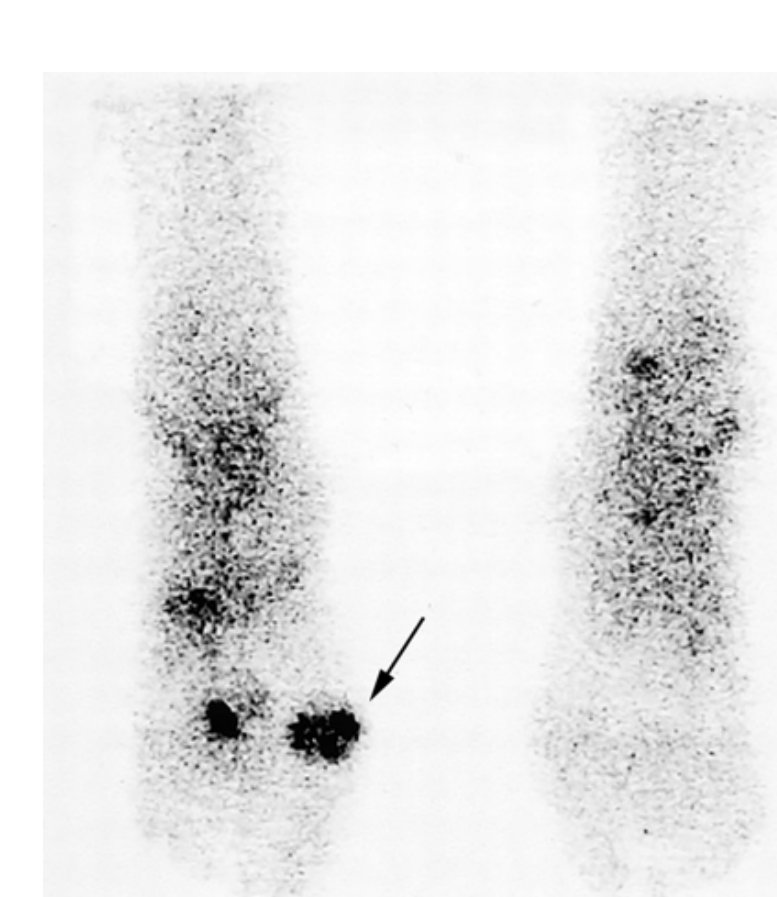

Figure 4. Three-phase bone scintigraphy of the foot: increased uptake in the first metatarsophalangeal joint indicating sesamoiditis (arrow).

and sclerotic edges of the divided fragments. (Figure 2) Osteonecrosis is characterized by radiolucency, bone sclerosis and fragmentation in the later stage of the disease. (Figure 3) If an infection is present, radiographs may show focal osteopenia, periostal reaction (periostitis), focal bone lysis or cortical loss etc.

Bone scintigraphy is not used regularly, but it may be helpful in sesamoiditis diagnostics ${ }^{32}$. Still, in almost $30 \%$ of cases the radiotracer uptake is increased in the area on the plantar side of the head of first metatarsal bone, so results have to be interpreted with caution. (Figure 4) Computerized tomography (CT) is used for distinction of fractures and early stage of stress fractures of sesamoid bones from other pathological conditions $s^{33}$. Technetium-99m methylene diphosphonate single-proton emission computed tomography (SPECT) combines sensitivity of the radionuclide study with the superior anatomical detail of CT, enabling better localization of pathological uptake and evaluation of associated structural changes ${ }^{34}$. (Figure 5) Disadvantage of those diagnostic methods (CT and SPECT) is ionizing radiation.

Ultrasound examination may be useful for determination of soft tissue edema, which is often overlooked on a clinical examination. Examination may show irregularity of the bony surfaces as well as discontinuity in case of fragmentation or fracture.

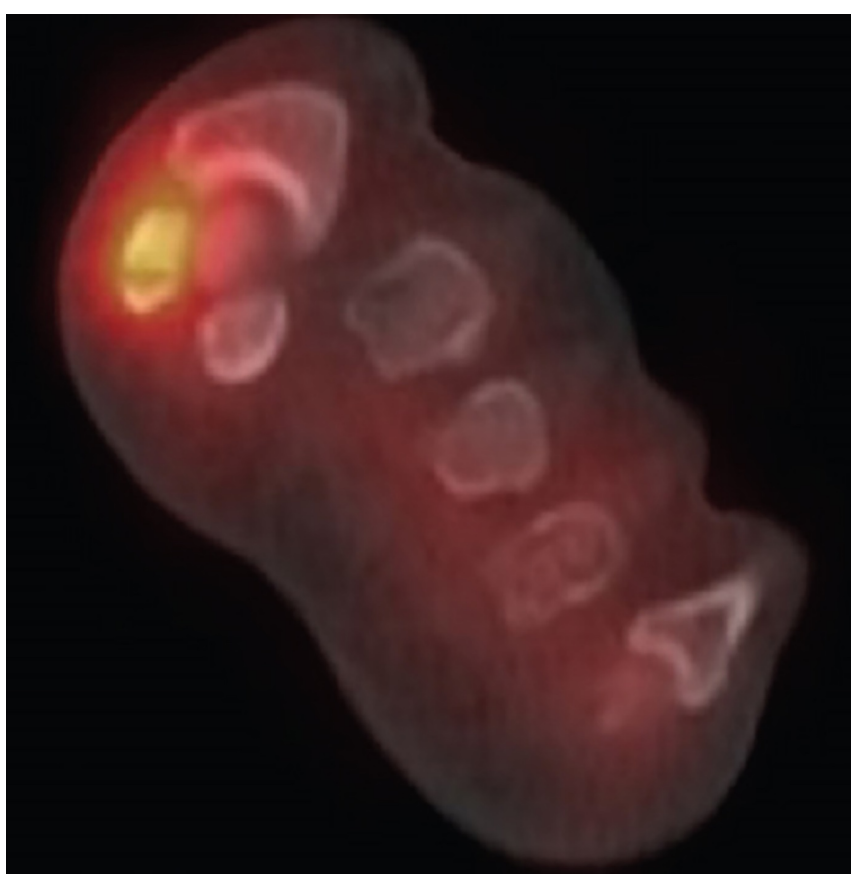

Figure 5. The coronal oblique fused technetium-99m methylene diphosphonate single-proton emission computed tomography image: increased uptake of tibial sesamoid bone representing increased osteoblastic activity of reactively edematous bone due to stress fracture.

Magnetic resonance imaging (MRI) allows differentiation between bony pathology and soft tissue conditions. Because of possibility of MRI to show small amount of bone marrow edema, it may detect early stage of stress reaction, before stress fracture is developed.

Coronal plane on MRI, perpendicular to the long axis of metatarsal bones, proved to be most useful, with sagittal plane also providing valuable information, while axial plane showed to be of least importance in sesamoiditis diagnostics. T1 images highlight fat, and T2 images highlight edema. While taking T2 images it is helpful to use short inversion time interval which is used to suppress fat tissue and to improve visualization of bone edema ${ }^{2}$. (Figure 6)

\section{TREATMENT}

Sesamoiditis management is primarily conservative and it depends on duration and severity of the condition. Treatment process is fairly complex because it is hard to avoid putting pressure on sesamoid bones during gait. In the initial phase of treatment, a cast or a lower leg orthosis is used in order to relieve pressure from the foot. In mild cases, it is possible to put a soft padding under the first MTP joint. Orthotic insoles customized according to pedobarography findings may be useful for solving biomechanical deformities that could have
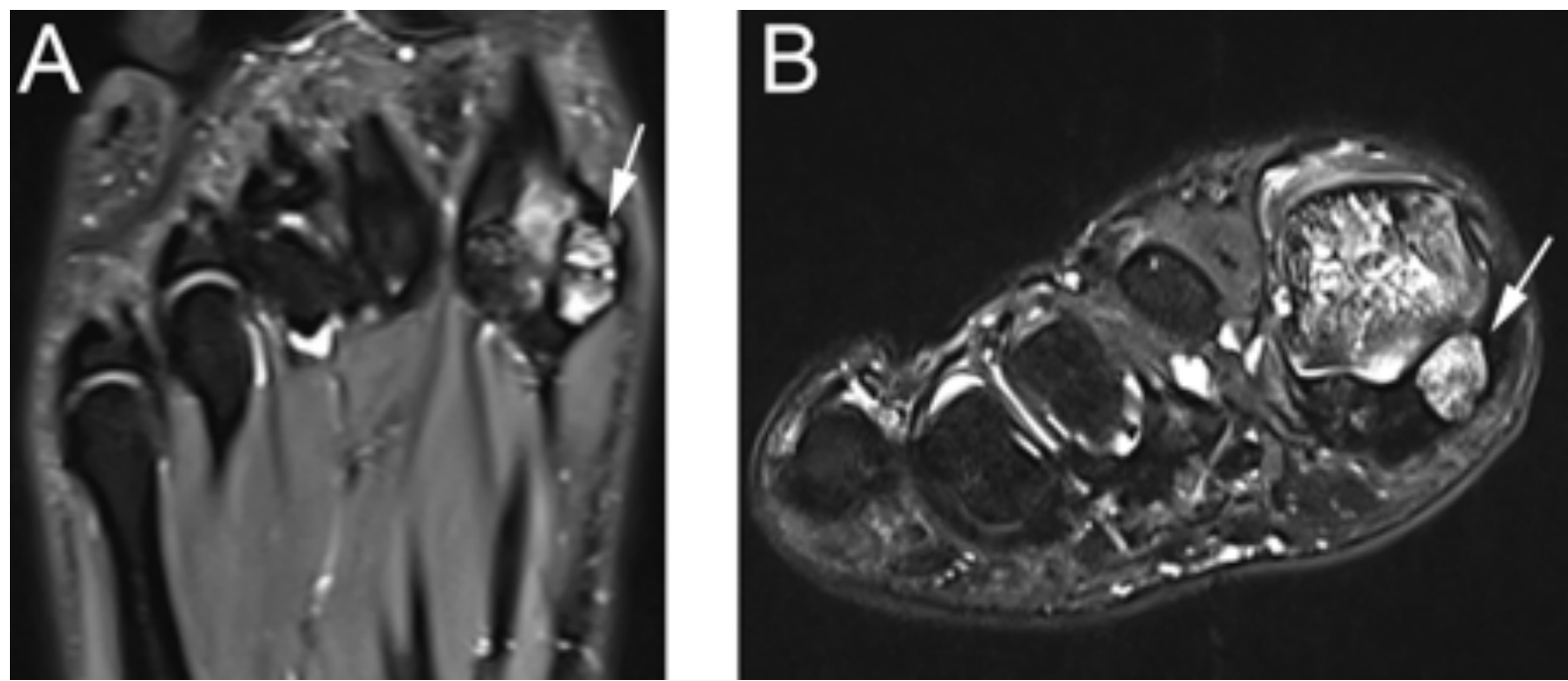

Figure 6. Axial (A) and coronal (B) MR images of the foot show bone marrow edema of the tibial sesamoid bone as a sign of impingement between fragments of the bipartite sesamoid (arrow). Fibular sesamoid bone has normal signal intensity of the bone marrow. 


\section{Review Article}
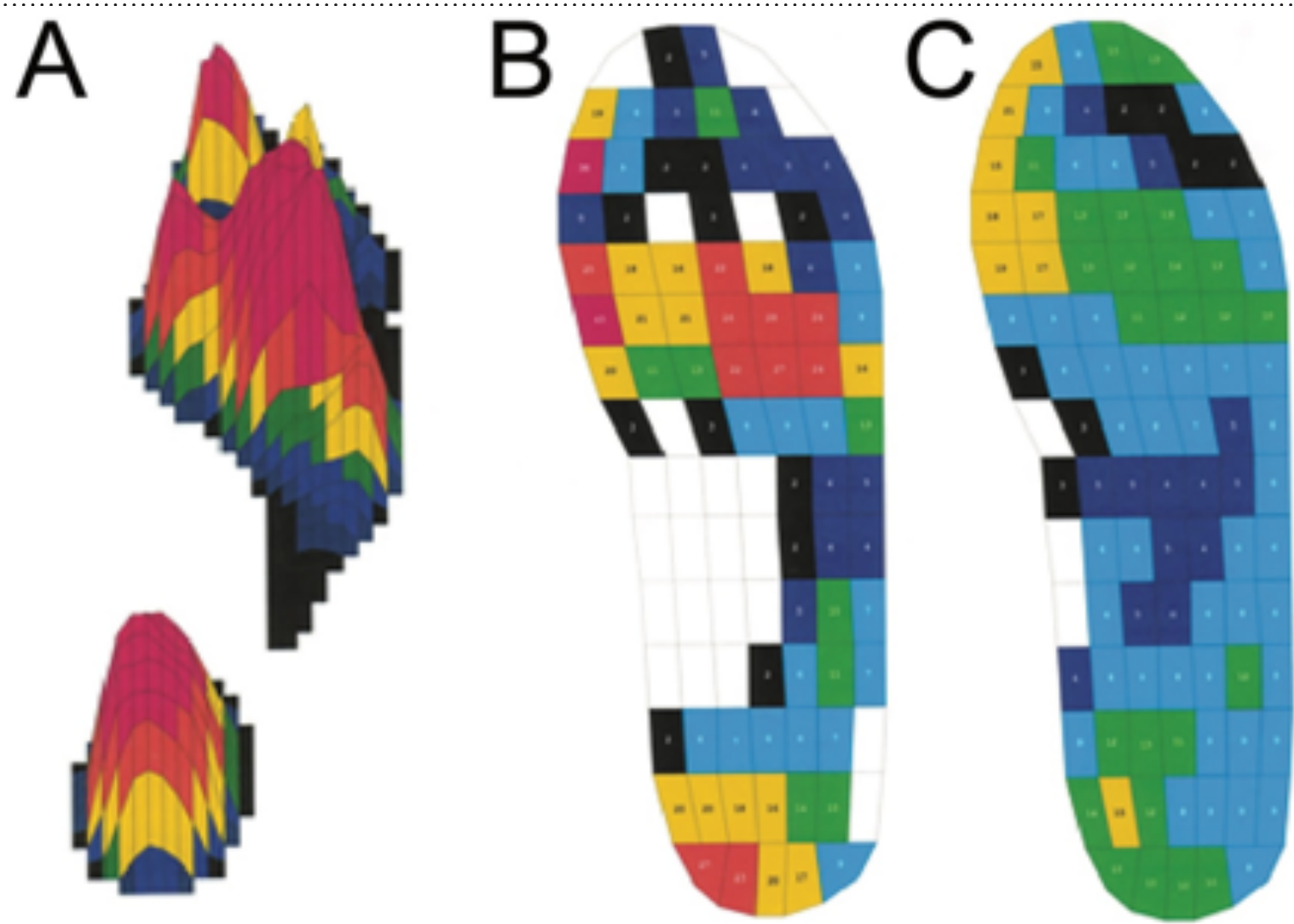

Figure 7. Pedobarogram of an athlete suffering from sesamoiditis: A) three dimensional demonstration of pedobarogram (increased plantar pressure in the area of sesamoid bones, concave form of foot-pes cavus); B) plantar pressures measured in shoes; C) plantar pressure measured in shoes after applying CAD/CAM insole (decreased pressure in the area of sesamoid bones; increased contact area)

led to development of sesamoiditis. (Figure 7) Specific pads placed under the first MTP joint in order to prevent the great toe from dorsiflexion proved to be a very effective conservative treatment option.

Nonsteroidal anti-inflammatory drugs can be used for pain relief, while the use of corticosteroid injections showed relief of symptoms, but is discussable because of its side effects, especially when used repeatedly. Saxena A. et al. described positive effect of radial soundwaves for sesamoidopathy in athletes ${ }^{35}$. Surgical treatment is considered if conservative methods fail to provide sufficient management of the condition. It should be considered with caution regarding the role that sesamoid bones play in the great toe biomechanics. Sesamoidectomy may be performed after failed conservative management of different pathological conditions, ie. non-union or stress fractures, osteonecrosis, chondromalacia, infections etc. Studies show that this operation proved to be satisfying with $94.4 \%$ of patients returning to sports, of which $90.0 \%$ returning to level of activity they had prior to acquiring sesamoiditis. However, overall complication rate was $22.5 \%$ and the revision rate was $3.0 \% 36,37,38,39$. Nevertheless, in some cases surgery is inevitable. Nowadays, it is possible to perform minimally invasive surgery in terms of arthroscopic sesamoidectomy, using different portals for approaching to either tibial or fibular sesamoid bone.

\section{Conclusion}

As the modern technologies are evolving and thus providing the possibility to diagnose etiology of injuries and other conditions that affect sesamoid bones, it is becoming obsolete to use the clinical diagnosis of sesamoiditis. Nevertheless, most of this conditions are still treated in the same manner. Novel concepts of treatment provide good results, with most of patients being able to return to the previous level of activity they had before acquiring any of above mentioned conditions.

\section{AUthOR CONTRIBUTIONS:}

All authors listed have made a substantial, direct and intellectual contribution to the work, and approved it for publication.

\section{LITERATURE:}

1. Srinivasan R. The hallucal-sesamoid complex:normal anatomy, imaging and pathology.Semin Musculoskelet Radiol. 2016;20:224-232. doi: $10.1055 / \mathrm{s}-0036-1581121$

2. Cohen BE. Hallux sesamoid disorders. Foot Ankle Clin. 2009;14(1):91-104. doi: 10.1016/j.fcl.2008.11.003

3. Scranton PE Jr, Rutkowski R. Anatomic variations in the first ray: Part II. Disorders of the sesamoids. Clin Orthop Relat Res. 1980;(151):256-64.

4. Kadakia AR, Molloy A. Current concepts review: traumatic disorders of the first metatarsophalangeal joint and sesamoid complex. Foot Ankle Int. 2011;32(8):834-9. Boike A, Schnirring-Judge M,
McMillin S. Sesamoid disorders of the first metatarsophalangeal joint. Clin Podiatr Med Surg. 2011;28(2):269-85. doi: 10.3113/ FAI.2011.0834

5. Boike A, Schnirring-Judge M, McMillin S. Sesamoid disorders of the first metatarsophalangeal joint. Clin Podiatr Med Surg. 2011;28(2):269-85. doi: 10.1016/j.cpm.2011.03.006 6. Nwawka OK, Hayashi D, Diaz LE, Goud AR, Arndt WF 3rd, Roemer FW, Malguria N, Guermazi A. Sesamoids and accessory ossicles of the foot: anatomical variability and related pathology. Insights Imaging. 2013;4(5):581-93. doi: 10.1007/s13244-013-0277-1. 7. Lee SYS, Tan TJ, Yan YY. Fracture of a Bipartite Medial Hallux Sesamoid Masquerading as a Tripartite Variant: A Case Report and 
Review of the Literature. J Foot Ankle Surg. 2019;58(5):980-983. doi: $10.1053 /$ j.jfas.2018.12.019

8. Alexa O, Popia I. Stress fracture of the internal sesamoid bone of the first metatarsophalangeal joint. Case report. Rev Med Chir Soc Med Nat Iasi. 2005;109(4):822-4. (in Romanian)

9. Van Hal, M. E., Keene, J. S., and Lange, T. A., Stress fractures of the great toe sesamoids. Am. J. Sports Med. 1982;10:122-128. doi: $10.1177 / 036354658201000212$

10. Robertson GAJ, Goffin JS, Wood AM. Return to sport following stress fractures of the great toe sesamoids: a systematic review. Br Med Bull. 2017;122(1):135-149. doi: 10.1093/bmb/ldx010

11. Coughlin MJ, Kemp TJ, Hirose CB. Turf toe: soft tissue and osteocartilaginous injury to the first metatarsophalangeal joint. Phys Sportsmed. 2010;38(1):91-100. doi: 10.3810/psm.2010.04.1766 12. Bartosiak K, McCormick JJ. Avascular Necrosis of the Sesamoids. Foot Ankle Clin. 2019;24(1):57-67. doi: 10.1016/j.fcl.2018.09.004 13. Garrido IM, Bosch MN, González MS, Carsí VV. Osteochondritis of the hallux sesamoid bones. Foot Ankle Surg. 2008;14(4):175-9. doi: $10.1016 /$ j.fas.2008.02.004

14. Frankel, J. P. and Harrington, J. Symptomatic bipartite sesamoids. J. Foot Surg. 1990;29:318-323.

15. Favinger JL, Porrino JA, Richardson ML, Mulcahy H, Chew FS, Brage ME. Epidemiology and imaging appearance of the normal $\mathrm{Bi}-/$ multipartite hallux sesamoid bone. Foot Ankle Int. 2015;36(2):197202. doi: $10.1177 / 1071100714552484$

16. Kumar S, Kadavigere R, Puppala R, Ayachit A, Singh R. Subhallucal Interphalangeal Sesamoiditis: A Rare Cause of Chronic Great Toe Pain. J Clin Diagn Res. 2015;9(5):TD01-2. doi: 10.7860/ JCDR/2015/13210.5870

17. Kanatli U, Ozturk AM, Ercan NG, Ozalay M, Daglar B, Yetkin H. Absence of the medial sesamoid bone associated with metatarsophalangeal pain. Clin Anat. 2006;19(7):634-9. doi: 10.1002/ca.20282 18. Rodeo SA, Warren RF, O’Brien SJ, Pavlov H, Barnes R, Hanks GA. Diastasis of bipartite sesamoids of the first metatarsophalangeal joint. Foot Ankle. 1993;14(8):425-34. doi: $10.1177 / 107110079301400801$

19. Pećina M, Bojanić I. Overuse Injuries of the Musculoskeletal System, Second Edition, CRC Press, Boca Raton-London-New York-Washington,D.C. 2004; pp 296-298.

20. Hardaker, W. T., Jr. Foot and ankle injuries in classical ballet dancers. Orthop. Clin. Am. 1989;20:621-627.

21. McBryde, A. M. and Anderson, R. B. Sesamoid foot problems in the athlete. Clin. Sports Med. 1988;7:51-60.

22. Schein AJ, Skalski MR, Patel DB, White EA, Lundquist R, Gottsegen CJ, Forrester DM, Matcuk GR Jr. Turf toe and sesamoiditis: what the radiologist needs to know. Clin Imaging. 2015;39(3):380-9. doi: 10.1016/j.clinimag.2014.11.011

23. Mason LW, Molloy AP. Turf Toe and Disorders of the Sesamoid Complex. Clin Sports Med. 2015;34(4):725-39. doi: 10.1016/j. csm.2015.06.008

24. Brophy RH, Gamradt SC, Ellis SJ, Barnes RP, Rodeo SA, Warren RF, Hillstrom H. Effect of turf toe on foot contact pressures in professional American football players. Foot Ankle Int. 2009;30(5):405-9. doi: 10.3113/FAI-2009-0405
25. George E, Harris AH, Dragoo JL, Hunt KJ. Incidence and risk factors for turf toe injuries in intercollegiate football: data from the national collegiate athletic association injury surveillance system. Foot Ankle Int. 2014;35(2):108-15. doi: 10.1177/1071100713514038 26. McCormick JJ, Anderson RB. The great toe: failed turf toe, chronic turf toe, and complicated sesamoid injuries. Foot Ankle Clin. 2009;14(2):135-50. doi: 10.1016/j.fcl.2009.01.001 27. Hotfiel T, Carl HD, Jendrissek A, Swoboda B, Barg A, Engelhardt M. [Die Turf-Toe-Verletzung - ein Hyperextensionstrauma der Großzehe]. Sportverletz Sportschaden. 2014;28(3):139-45. doi: 10.1055/s-0034-1366873 (in German)

28. Allen MA, Casillas MM. The passive axial compression (PAC) test: a new adjunctive provocative maneuver for the clinical diagnosis of hallucal sesamoiditis. Foot Ankle Int. 2001;22(4):345-6. doi: $10.1177 / 107110070102200414$

29. Sanders TG, Rathur SK. Imaging of painful conditions of the hallucal sesamoid complex and plantar capsular structures of the first metatarsophalangeal joint. Radiol Clin North Am. 2008;46(6):107992. doi: 10.1016/j.rcl.2008.09.001

30. Waldrop NE 3rd, Zirker CA, Wijdicks CA, Laprade RF, Clanton TO. Radiographic evaluation of plantar plate injury: an in vitro biomechanical study. Foot Ankle Int. 2013;34(3):403-8. doi: $10.1177 / 1071100712464953$

31. Yildirim Y, Cabukoglu C, Erol B, Esemenli T. Effect of metatarsophalangeal joint position on the reliability of the tangential sesamoid view in determining sesamoid position. Foot Ankle Int. 2005;26(3):247-50. doi: 10.1177/107110070502600311

32. Yang RH, Chu YK. Hallucal sesamoiditis manifested on bone scan. Clin Nucl Med. 2013;38(12):1019-21.

33. Welck MJ, Singh D, Cullen N, Goldberg A. Evaluation of the 1st metatarso-sesamoid joint using standing CT - The Stanmore classification. Foot Ankle Surg. 2018;24(4):314-319. doi: 10.1016/j. fas.2017.03.005

34. Sharma P, Singh H, Agarwal KK, Sudhir KS, Khangembam BC, Bal C, Malhotra A, Kumar R. Utility of (99m)Tc-MDP SPECT-CT for the diagnosis of sesamoiditis as cause of metatarsalgia. Indian J Nucl Med. 2012;27(1):45-7. doi: 10.4103/0972-3919.108865 35. Saxena A, Yun A, Patel R, Gerdesmeyer L, Maffulli N. Radial Soundwave for Sesamoidopathy in Athletes: A Pilot Study. J Foot Ankle Surg. 2016;55(6):1333-1335. doi: 10.1053/j.jfas.2016.07.024 36. Shimozono Y, Hurley ET, Brown AJ, Kennedy JG. Sesamoidectomy for Hallux Sesamoid Disorders: A Systematic Review. J Foot Ankle Surg. 2018;57(6):1186-1190. doi: 10.1053/j.jfas.2018.03.044 37. Taylor CF, Butler M, Parsons SW. Problems associated with the excision of the hallux sesamoids. Foot Ankle Clin. 2014;19(3):425-36. doi: $10.1016 /$ j.fcl.2014.06.014

38. Alshouli MT, Lin A, Kadakia AR. Simultaneous first metatarsophalangeal joint arthrodesis and sesamoidectomy with a single dorsomedial incision. Foot Ankle Spec. 2014;7(5):403-8 doi: $10.1177 / 1938640014545217$

39. Ford SE, Adair CR, Cohen BE, Davis WH, Ellington JK, Jones $\mathrm{CP}$, Anderson RB. Efficacy, Outcomes, and Alignment Following Isolated Fibular Sesamoidectomy via a Plantar Approach. Foot Ankle Int. 2019;1071100719 doi: 10.1177/1071100719868734 